KOLESNYKOVA T. O.

Editor-in-Chief,

PhD Social Sciences, Communication,

Senior researcher,

Director of the Scientific and Technical Library

Dnipro National University of Railway Transport

named after Academician V. Lazaryan (Dnipro, Ukraine),

e-mail: chief.library@ gmail.com, ORCID 0000-0002-4603-4375

\title{
READINESS OF UNIVERSITY LIBRARIES FOR ONLINE COMMUNICATION AND INTERACTION: UNILIBNSD-2020 INTERNATIONAL CONFERENCE
}

A new (5th) issue of the journal "University Library at a New Stage of Social Communications Development. Conference Proceedings" is presented. Full-format papers were selected, reviewed and recommended by the members of the international editorial board of the similarly-named conference (UniLibNSD-2020).

The topic of the conference "University Library at a New Stage of Social Communications Development" in 2020 is "Open Science, Open Access and Open Educational Resources: New Opportunities for Libraries."

A fantastic experience of bringing together opinions of the leaders from different countries in the field of Library and Information Science (LIS) in a hybrid (blended) format forum is presented!

The main topics of the presented articles are determined, the peculiarity of LIS university researchers in the choice of topics is indicated.

Keywords: Conference Proceedings; university library; blended conference experience; UniLibNSD-2020 International Conference; Library and Information Science; Library of DNURT; Ukraine

Dear readers, authors, and colleagues,

Today we present the new (V) issue of the journal "University Library at a New Stage of Social Communications Development. Conference Proceedings.” Full-format papers were selected, reviewed and recommended by the members of the international editorial board of the similarly-named conference (UniLibNSD-2020).

The subject of the conference "University Library at a New Stage of Social Communications Development" in 2020 is "Open Science, Open Access and Open Educational Resources: New Opportunities for Libraries.” (http://conflib.diit.edu.ua/Conf_univ_Library2020).

The International Conference was initiated by Scientific and Technical Library of Dnipro National University of Railway Transport named after Academician V. Lazaryan (DNURT Library; https://library.diit.edu.ua) and took place on October 8-9, 2020 in the DNURT Conference Hall (Dnipro, Ukraine).

The organizing committee closely monitored the situation with COVID-19 and restrictions on physical movement. We realized that in the current period of dramatic uncertainties, virtual conferences (regional, global) may be the only place and time when we have direct access to the leaders of academic directions, experts and other recognized specialists.

The great news is that in the summer and autumn of 2020, Dnipro (Ukraine) was in a fairly safe epidemic zone. Therefore, we were glad to meet with the conference participants in various formats - physically and online. The blended conference experience or hybrid conference offered participants a safe, most efficient and affordable way to combine and interact, physically and online. 
It was a fantastic experience bringing together opinions of the leaders from different countries in the Library and Information Science (LIS) field in a hybrid (blended) forum!

The International Organizing Committee has done a great job keeping all the safety measures for the 57 physical participants and staff. But the bulk of the LIS researchers and practitioners (127 people) communicated online in ZOOM.

Specialists and scientists in the field of LIS and higher education from eight countries of the world (Poland, Belarus, Lithuania, Sweden, South Africa, Kazakhstan, the Philippines and Ukraine) attended the conference.

Thanks to them, the forum has become a unique physical and virtual platform for scientific discussions, constructive exchange of information, best practices, lessons and master classes.

Video presentations and reports revealed already developed and innovative practices, current events and possible vectors for the development of university libraries in the world under conditions of uncertainty caused by the COVID-19 pandemic. Abstracts and presentations are available at http://conflib.diit.edu.ua/Conf_univ_Library2020/schedConf/presentations.

Changing strategies and priorities in the activities of libraries of higher education institutions set the topics for the speeches and discussions:

- COVID-19 pandemic amplifies and accelerates trends for libraries to invest in digital resources and services.

- Today is exactly the time when every library needs to immediately focus on open electronic educational resources (OER).

- Open science, open access, having changed the processes and management of scientific communications, have provided new opportunities for university libraries to demonstrate their contribution to the development of distance learning and research.

- Libraries of higher education institutions have over the years created digital collections, expanded the range of digital services and provided the digital infrastructure of their institutions, which made them one of the most digital structures of academic activity.

- Academic integrity policies and practices in universities around the world are greatly enhanced and disseminated due to libraries.

- Assessment of scientific resources, bibliometry, scientometrics, new and emerging metrics, have become mandatory elements of library activities for many universities around the world.

- The use of social networks as a tool for interacting with users is becoming increasingly popular.

- Psychological support and practical aspects of the use of innovative psychological tools during psychological support of librarians.

- The message of the world's libraries, that environmental friendliness is the answer to the challenges of our time sounds more and more confidently and louder: green libraries and sustainable development

- and much more

At the same time, the peculiarity of LIS university researchers is that in addition to conducting research focused only on library science, there is a need to conduct research in various disciplines that are relevant to their institutions.

The common thread in all the reports was the belief that the pandemic should be a turning point for all university libraries in expanding their contacts with users, with each other, with all 
the persons concerned. And this test of the library's readiness for online communication and interaction gave a positive result!

Of the many presented conference reports, the members of the international editorial board selected the highest quality papers, which are presented in this (5th) issue of the journal "University Library at a New Stage of Social Communications Development. Conference Proceedings."

The publication provides direct open access to its content, based on the following principle: free open access to research results enhances global knowledge sharing.

The international editorial board appreciates the contribution of each author. We sincerely thank our readers for their interest in UniLibNSD-2020, our reviewers for their competence, delicacy and goodwill.

We sincerely wish our partners and readers good health, success and confidence that the global twilight will surely disappear soon and the time for sunny days will come!

КОЛЕСНИКОВА Т. О.

Головний редактор, канд. наук із соціальних комунікацій, с.н.с., директорка науково-технічної бібліотеки, Дніпровський національний університет залізничного транспорту імені академіка В. Лазаряна (Дніпро, Україна), e-mail: chief.library@gmail.com, ORCID 0000-0002-4603-4375

\section{ГОТОВНІСТЬ УНІВЕРСИТЕТСЬКИХ БІБЛІОТЕК ДО ОНЛАЙН-СПІЛКУВАННЯ I ВЗАСМОДІї: МІЖНАРОДНА КОНФЕРЕНЦІЯ UNILIBNSD-2020}

Представлено новий (5-ий) випуск журналу "University Library at a New Stage of Social Communications Development. Conference Proceedings". Повноформатні статті були відібрані, рецензовані та рекомендовані членами міжнародної редакційної ради однойменної конференції (UniLibNSD-2020).

Тема конференції "University Library at a New Stage of Social Communications Development" в 2020 р. - "Відкрита наука, відкритий доступ та відкриті освітні ресурси: нові можливості для бібліотек".

Представлений фантастичний досвід об'єднання лідерів думок різних країн в області Library and Information Science (LIS) при проведенні форуму гібридного (змішаного) формату!

Визначено основні теми представлених статей, вказана особливість університетських дослідників LIS у виборі тем.

Ключові слова: Conference Proceedings; бібліотека університету; blended conference experience; міжнародна конференція UniLibNSD-2020; Library and Information Science; Library of DNURT; Ukraine 